\section{FRESH STATE AND MECHANICAL PROPERTIES OF ULTRA-LIGHTWEIGHT FOAMED CONCRETE INCORPORATING ALKALI TREATED BANANA FIBRE}

\author{
Mohammed Hassan Nensok*, Md Azree Othuman Mydin, Hanizam \\ Awang
}

School of Housing, Building and Planning, Universiti Sains Malaysia, 1 1800, Penang, MALAYSIA
Article history

Received

14 April 2021

Received in revised form

4 November 2021

Accepted

9 November 2021

Published Online

20 December 2021

*Corresponding author nensok@student.usm.my

\section{Graphical abstract}
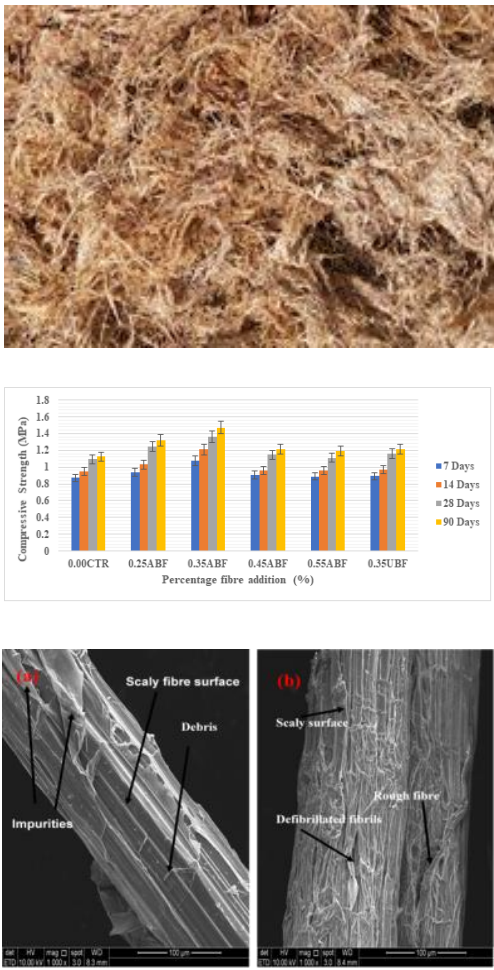

\section{Abstract}

For a Lightweight Foamed Concrete (LFC) to efficiently function as an energy-saving building material, its self-weight (density) should be reduced. However, the problem associated with a reduced density is a decline in strength. To improve the mechanical properties of LFC, this research attempts to integrate banana fibre into LFC composite with a focus on fresh and harden state properties. An Ultra-Lightweight Foamed Concrete (ULFC) with a density of $600 \mathrm{~kg} / \mathrm{m}^{3}$ was produced with the inclusion of treated and untreated banana fibres. The volume fractions of banana fibre added into LFC were $0.00 \%$ (control specimen), $0.25 \%, 0.35 \%, 0.45 \%$ and $0.55 \%$. In addition, an optimised batch mix of ULFC reinforced with $0.35 \%$ untreated banana fibre was produced. The batches were tested for rheological, physical, and mechanical properties. Findings reveal that the workability of ULFC composites decrease with increase in fibre addition. The compressive, flexural, and tensile strengths of the alkali-treated composites were higher than the untreated banana fibre composite. SEM micrograph reveals that defibrillation of bundle fibrils due to cleaning the surface amorphous hemicellulose, lignin and pectin of the alkali-treated fibre, leads to rough surfaces and increase surface area resulting in better interfacial adhesion of the fibre with cement matrix.

Keywords: Foamed concrete, banana fibre, rheology, flexural, compression, porosity

\begin{abstract}
Abstrak
Untuk Konkrit Ringan Berbusa (LFC) berfungsi dengan berkesan sebagai bahan binaan penjimatan tenaga, berat LFC (ketumpatan) harus dikurangkan. Walau bagaimanapun, masalah yang berkaitan dengan pengurangan ketumpatan adalah penurunan kekuatan. Untuk meningkatkan sifat mekanikal LFC, penyelidikan ini cuba menggabungkan serat pisang ke dalam komposit LFC yang memfokuskan pada 2 parameter utama iaitu sifat keadaan segar dan sifat keadaan keras. Konkrit Ultra Ringan Berbusa (ULFC) dengan ketumpatan $600 \mathrm{~kg} / \mathrm{m}^{3}$ telah dihasilkan dengan memasukkan serat pisang yang dirawat dan tidak dirawat. Pecahan isipadu serat pisang ditambahkan ke dalam LFC adalah 0,00\% (spesimen kawalan), $0,25 \%, 0,35 \%, 0,45 \%$ dan $0,55 \%$. Sebagai tambahan, campuran komposit ULFC yang dioptimumkan yang diperkuat dengan serat pisang yang tidak dirawat $0.35 \%$ dihasilkan pada masa yang sama. Kumpulan diuji untuk sifat reologi, fizikal, dan mekanikal. Penemuan menunjukkan bahawa kebolehkerjaan ULFC menurun dengan peningkatan pecahan isipadu serat. Kekuatan mampatan, lenturan, dan tegangan serat pisang yang dirawat dengan alkali lebih tinggi daripada komposit serat pisang ULFC yang tidak dirawat. Mikrograf SEM mendedahkan bahawa defibrilasi fibril berlaku kerana
\end{abstract}


pembersihan permukaan hemiselulosa amorfus, lignin dan pektin dari serat yang diperlakukan dengan alkali, yang membawa kepada permukaan kasar dan meningkatkan luas permukaan sehingga menghasilkan lekatan serat antara muka yang lebih baik dengan matriks simen.

Kata kunci: konkrit berbusa, serat pisang, reologi, lenturan, mampatan, keliangan

(C) 2022 Penerbit UTM Press. All rights reserved

\subsection{INTRODUCTION}

Lightweight Foamed Concrete (LFC) is an aerated concrete in which air bubbles are uniformly distributed into a cementitious mortar in the form of foam to produce a cellular concrete of varying densities. Depending on the quantity of foam, density can differ from $300-1900 \mathrm{~kg} / \mathrm{m}^{3}$ [1]. Thus, LFC is flexible and characterised by numerous advantages. LFC has good workability, excellent thermal and acoustic properties, fire resistance performance, freeze-thaw resistance, low self-weight, and ability to mix with numerous supplementary cementitious materials (industrial and agricultural wastes [2, 3]. All these advantages make LFC a green construction material, primarily used as energy-efficient building materials to produce walls, floors and roofs.

However, to achieve the best energy-saving properties, the density of LFC must be between 300-800 $\mathrm{kg} / \mathrm{m}^{3}$. However, the problem associated with reduced density is a decline in strength. LFC of a low density is referred to as Ultra-Lightweight Foamed Concrete (ULFC). In contrast, LFC of densities ranging from 800$1900 \mathrm{~kg} / \mathrm{m}^{3}$ is referred to as structural LWFC Elshawawi [4]. ULFC, with a density ranging from $300-800 \mathrm{~kg} / \mathrm{m}^{3}$, better satisfies all the requirement for excellent energyefficient building materials but possesses some shortcomings in terms of mechanical properties especially the flexural and tensile strengths. Hence, this study had been carried out to examine the potential utilization of banana fibre to enhance the mechanical properties of ULFC.

Mechanical properties such as splitting tensile, flexural, impact resistance and compressive strengths of ULFC are mostly improved by incorporating synthetic or natural fibres. Synthetic fibres such as glass, polypropylene, polyvinyl alcohol and carbon have been investigated in LFC [5-8]. However, the synthetic fibre in low-density LFC is not advisable for several reasons. Synthetic fibres, such as steel and glass fibres, have a higher density or specific gravity than natural fibres. As a result, they are inappropriate for ULFC composites [9]. Furthermore, as compared to synthetic fibres, the lightness and high porosity of natural fibre result in superior thermal and acoustic qualities of ULFC. In general, natural fibre is green and environmentally friendly, with very little embodied energy when compared to synthetic natural fibre $[10,11]$. Besides, natural fibre is recyclable, renewable, non-toxic and sustainable.
Banana fibre is a natural fibre obtained from the pseudostem parts of a banana plant. The banana plant is a popular herbaceous plant and one of the most common fruit found growing worldwide. The plant is a perennial herb that grows up to 3-7 m annually and produces a succulent sweet fruit cherish which is rich in vitamins and nutrients.

Despite all the benefits associated with the choice of banana fibre in this study, it is characterised by cellulose, hemicellulose, lignin, pectin, and ash, limiting its application in the cementitious matrix. Lignocellulose fibres degrade by mineralisation in alkaline environments of the cement matrix. The solution to this challenge was suggested by Vo and Navard [12] to includes fibre modifications and matrix modifications. The former involves physical treatment, coating, impregnation, and chemical treatment. The latter involves accelerated carbonation and the use of pozzolanas. This research focused on using the chemical treatment technique of improving the mineralisation of banana fibre in the cement matrix. The method chosen is the alkali treatment using $\mathrm{NaOH}$ solution to clean the surfaces of the natural fibre. Alkali treatment of natural fibres has been reported to improve several mechanical and durability properties of vegetable fibres in cementitious composite [13-15].

Research on ULFC reinforced with either synthetic or natural fibre is not new. As far as synthetic fibres are concerned, numerous research efforts had been undertaken. El Zareef \& Schlaich [16] undertook a study in which an ULFC was produced with glass fibre and used to produce a model house. The average compressive strength for the $760 \mathrm{~kg} / \mathrm{m}^{3}$ density ULFC, atday-56 was $7 \mathrm{~N} / \mathrm{mm}^{2}$. Falliano et al. [17], conducted another research effort in which extrudable ULFC was produced with densities of 400,600 and $800 \mathrm{~kg} / \mathrm{m}^{3}$. Two types of fibre were varied, which were bidirectional glass fibre and discrete short polymer fibre. Their Findings reveal that a great improvement in bending strength was observed due to inclusion of the glass fibre mesh which recorded a maximum of $1700 \%$ enhancement for the density of $400 \mathrm{~kg} / \mathrm{m}^{3}$. A study was reported by Luo et al. [18], using multi-wall carbon nanotubes reinforced ULFC of densities of 290 and 320 $\mathrm{kg} / \mathrm{m}^{3}$. Results reveal a $0.302 \mathrm{~N} / \mathrm{mm}^{2}$ compressive strength which was $27 \%$ higher than the plain sample. Yakovlev et al. [19] investigated the use of carbon nanotubes in FC at $300 \mathrm{~kg} / \mathrm{m}^{3}$. They found that carbon nanotubes reduced thermal conductivity while increasing compressive strength by $70 \%$ when 
compared to control. Batool and Bindiganavile [20] studied the fresh characteristics of ULFC reinforced with polypropylene fibre. When $0.2 \%$ polypropylene fibre was introduced, the spread diameter reduced, but the foam volume increased. Steshenko et al. [21] investigated the microstructure of $400-500 \mathrm{~kg} / \mathrm{m}^{3}$ ULFC reinforced with basalt and polypropylene fibre and found that porosity increased from $16.06 \%$ to $34.48 \%$, enhancing the composites' frost resistance. Yu [22] conducted research on $300-800 \mathrm{~kg} / \mathrm{m}^{3}$ ULFC reinforced with polypropylene fibre and the reduction in shrinkage caused by the addition of fibre. Pivarciova [23] investigated heat transport in a $600 \mathrm{~kg} / \mathrm{m}^{3}$ ULFC reinforced with PET fibres using interferometric measurements. The research team created a PET fibre reinforced ULFC with low thermal conductivity and high thermal insulating properties.

A limited research study has been conducted on ULFC reinforced with natural fibre. A group of researchers [24] performed a study utilising Recycled Cellulose Fibre (RCF) obtained from wastepaper. The study shows that utilising RCF in ULFC matrix of 600 $\mathrm{kg} / \mathrm{m}^{3}$ results in an ULFC with an increased compressive strength up to $35 \%$ compared to the control and an improved shrinkage property. Castillo-Lara et al. [15] uses alkali-treated and untreated henequin fibre to produce an ULFC of density $700 \mathrm{Kg} / \mathrm{m}^{3}$. The study shows a $25 \%$ and $22.5 \%$ increase in compressive strength, respectively, for the treated and untreated henequin fibre composite compared to the plain control at $1.5 \%$ fibre volume fraction. It also reported a $95 \%$ increase in tensile strength for the alkali-treated henequin fibre composite compared to the control at $1.5 \%$ fibre volume fraction.

From the preceding review, more studies are required to determine the properties of ULFC reinforced with natural fibres. Specifically, an investigation on properties of high porosity FC reinforced with banana fibre is lacking. To reduce this gap, this research investigated the fresh, physical and mechanical properties of ULFC reinforced with treated and untreated banana fibre. SEM analysis was employed to buttress the micrograph and porosity of the treated and untreated fibres.

\subsection{METHODOLOGY}

\subsection{Materials}

The materials used in the base mix production were river sand, cement, banana fibre and water. Protein based surfactant was used as the foaming agent (FA).

\subsubsection{Sand}

River sand was supplied from a nearby river in Penang, Malaysia. The sand was dried in the opened and sieved using a $1.18 \mathrm{~mm}$ sieve to make the sand finely uniform and remove deleterious materials. Bigger sand particles could break air bubbles and reduce foams' stability produced for FC Brady [25].

\subsubsection{Cement}

Ordinary Portland cement grade 53 complying with BS EN 197-1:2011 [26] was used. The cement is of bulk density $1286 \mathrm{~kg} / \mathrm{m}^{3}$ and specific gravity of 2.94 . The chemical composition of the cement type used was given in Table 1.

\subsubsection{Water}

Laboratory tab water which is clean and adequate for drinking is used as a solvent for the base mix. The tab water recorded a $\mathrm{pH}$ value of 6.97 and is also adopted for mixing the foaming agent. The water cement ratio used for this study was 0.45 .

\subsubsection{Foaming Agent}

The FA used in this research was obtained locally from DRN Technologies Sdn Bhd, Malaysia, with a trademark name Noraite PA-1. The FA is a protein foaming agent, which produced smaller, studier, closed and stable bubbles.

Table 1 Chemical composition of cement

\begin{tabular}{clc}
\hline S/No. & Oxides & Composition (\%) \\
\hline 1 & Silicon dioxide $\left(\mathrm{SiO}_{2}\right)$ & 16.84 \\
2 & Ferric Oxide $\left(\mathrm{Fe}_{2} \mathrm{O}_{3}\right)$ & 2.64 \\
3 & Calcium Oxide & 65.95 \\
4 & Aluminium Oxide & 5.82 \\
5 & Magnesium Oxide & 1.49 \\
6 & Potassium Oxide & 0.87 \\
7 & Phosphorus Oxide & 0.08 \\
8 & Sulphur Oxide & 2.76 \\
\hline
\end{tabular}

\subsubsection{Banana Fibre Processing}

Banana fibre was the main admixture used in the research and it was locally processed. The chemical composition of the untreated and alkali treated banana fibre is given in Table 2. Processing the pseudo stem is simply by direct in-situ extraction using a mechanical refiner. The mechanical refiner is a grinding machine. Figure 2 display a typical mechanical refiner used in extracting the banana fibre in this research. In this study, the cut banana fibre was chopped into smaller pieces, approximately $50 \mathrm{~mm} \pm 5 \mathrm{~mm}$ and grounded in a mechanical refiner. The grounded fibre was used as the raw banana fibre in the study, as shown in Figure 1(a). The raw banana fibre was subjected to alkali treatment using pellets of $\mathrm{NaOH}$ tablets mixed with water by weight volume w/v concentration of $6 \%$ for 24 hours. After the 24-hours of alkali treatment, the fibre was washed thoroughly with a weak solution of acetic acid and rinsed with water severally until the $\mathrm{pH}$ of the rinsing water reads 7 . The fibre is spread on a tray and dried in the open sun for 72 hours. Figure 1 show the alkali-treated and untreated banana fibre. The purpose of comparing alkali-treated and untreated banana fibre is to demonstrate the influence of alkali treatment on the physical, mechanical, and chemical properties of the 
fibres, which subsequently influenced the final properties of ULFC composites developed. The physical properties and mechanical properties of the banana fibre used in this research, both treated and untreated, is summarised in Table 3.

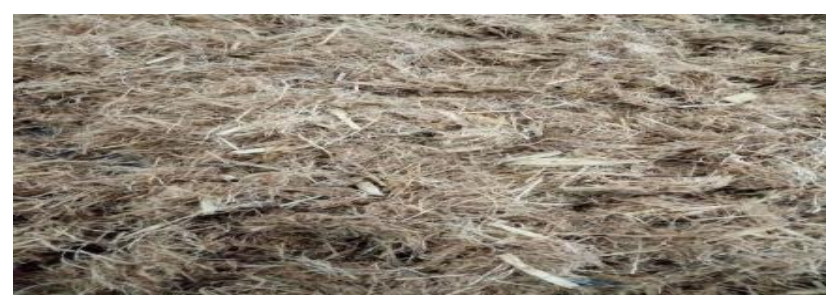

(a)

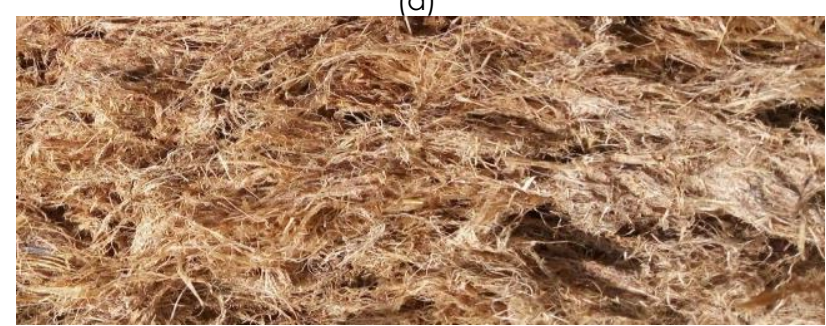

(b)

Figure 1 Banana fibre (a) Untreated raw banana fibre (top) (b) alkali treated banana fibre (bottom)

Table 2 Chemical composition of banana fibre

\begin{tabular}{ccc}
\hline Composition & Treated fibre & Untreated fibre \\
\hline Lignin & 15.10 & 10.05 \\
Hemicellulose & 18.60 & 6.16 \\
Cellulose & 53.20 & 68.56 \\
Extractive & 1.40 & 0.52 \\
Ash content & 0.96 & 6.35 \\
Moisture & 10.60 & 0.42 \\
\hline
\end{tabular}

Table 3 Physical and mechanical properties of treated and untreated banana fibre

\begin{tabular}{lll}
\hline Properties & Treated fibre & Untreated fibre \\
\hline Average length $(\mathrm{mm})$ & $30-50$ & $30-50$ \\
Diameter(mm) & 0.189 & 0.233 \\
Density (g/cc) & 1.35 & 1.23 \\
Tensile strength (MPa) & 487 & 266 \\
Young Modulus (GPa) & 28.7 & 19.3 \\
Elongation at break (\%) & 10.1 & 6.5 \\
\hline
\end{tabular}

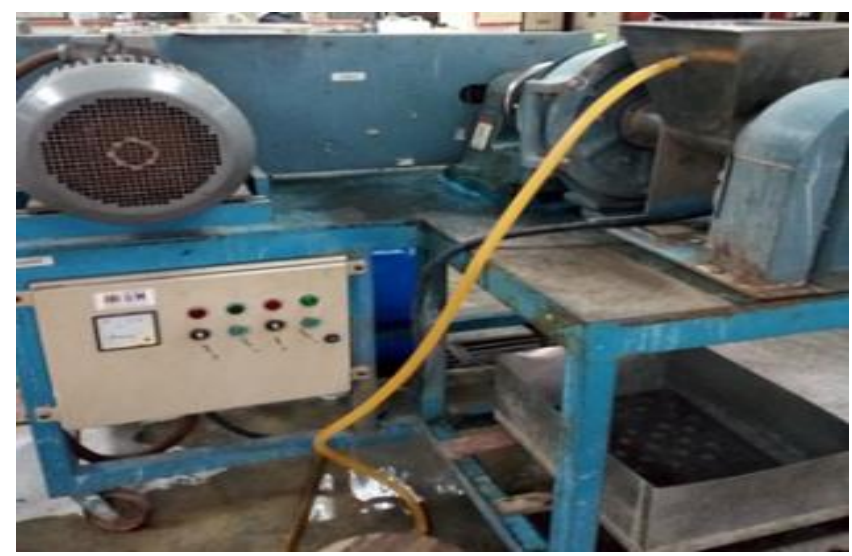

Figure 2 Mechanical refiner used in processing banana fibres

\subsection{Method}

\subsubsection{Banana Fibre ULFC Composite Production Process}

The mixture constituents to produce alkali-treated banana fibre ULFC of $600 \mathrm{~kg} / \mathrm{m}^{3}$ is shown in Table 4. The mix proportioning adopted for this work is based on cement: sand: water of 1:1.5:0.45. The banana fibre addition was calculated to the total volume weight of the mix. Five different mix batches, comprising of banana fibre content of $0.0 \%$ (control), $0.25 \%, 0.35 \%$, $0.45 \%$, and $0.55 \%$ by volume weight was produced. Besides, a mix was prepared for the untreated banana fibre composite using only the optimum percentage fibre addition of $0.35 \%$. The optimum percentage fibre addition was determined from a previous preliminary investigation conducted by Nensok et al. [27]. During each batch mix, the process of alkali treated banana fibre ULFC composite production consists of mixing the base mix (mortar) followed by generation and introducing the foam into the based mix. This method adopted is known as the pre-foaming method.

Dry and measured samples of the based mix (cement and sand) were first introduced into the mixer and allowed to mix for $3 \pm 2$ minutes. Then, $75 \% \pm 5 \%$ of the measured water was poured into the dry mix and allowed to be properly mixed for additional $3 \pm 2$ minutes. During which, the measured quantity of treated or untreated banana fibres are then added gradually. During mixing. care was taken to avoid balling of fibres or fibres sticking to the mixer's blades. After that, the remaining $25 \%$ measured water was then added, followed by additional water. The entire mixture is now referred to as the base mix.

Because of the hydrophilic nature of banana fibres caused by the presence of hydroxyl group $(-\mathrm{OH})$, additional water was added to ensure acceptable consistency despite utilising a $0.45 \% \mathrm{w} / \mathrm{c}$ ratio. Despite the alkali treatment, which decreases the hemicellulose and lignin that are responsible for the high hydroxyl group level (refer to Table 2), not all these components were eliminated. As a result, the alkalitreated banana fibre absorbed a lot of water, and more water was added to reach the requisite consistency of 180-240 mm spreadability as prescribed by Brady et al (25), before the foam was added to the base mix. Other reasons for using the $0.45 \% \mathrm{w} / \mathrm{c}$ were because, superplasticiser was not utilised in this experiment.

On the other side, Noraite PA-1 FA is mix with water using a mix ratio of $1: 30$, implying $1 \mathrm{~kg}$ of the protein FA to 30 litres of water. The mixture was agitated through a foaming machine and with the aid of gas pressure of about $450 \mathrm{kPa}$ to produce a foam of an approximate foam density of $60-80$ gram/litre. A total of 63 litres of the foam was calculated and produced and then introduced into each composite-based mix to produce a fibre reinforced ULFC composites of $700 \pm 50 \mathrm{~kg} / \mathrm{m}^{3}$ wet density. 


\subsubsection{Rheological Property Test}

Two different tests on the fresh property of BFRFC composite was conducted. These were the plastic density and workability tests of the composite. The plastic density of fresh composite was conducted following BS EN 12350-19 standard [28]. The test was conducted to determine the actual wet density of the FC composite. In FC design and production, the plastic or wet density knowledge is important as it helps predict the final target density. Another important fresh FC composite property is the workability of the composite. In this research, a spreadability flow test similar to the one described for self-consolidating concrete prescribed by ASTM C 1611/C 1611M:18 [29] was undertaken. However, in this research, the plastic density measurement and spreadability test apparatus used are a 1-litre cylindrical cup and an open-ended cylindrical container described by Brady, Watts, \& Jones [25].

Table 4 Mixture constituents of $600 \mathrm{~kg} / \mathrm{m}^{3}$ BFRFC composite

\begin{tabular}{|c|c|c|c|c|c|c|c|}
\hline Batch & $\begin{array}{l}\text { Cement } \\
(\mathrm{kg})\end{array}$ & $\begin{array}{l}\text { Sand } \\
\text { (kg) }\end{array}$ & $\begin{array}{l}\begin{array}{l}\text { Water } \\
(\mathrm{kg})\end{array} \\
\end{array}$ & $\begin{array}{l}\begin{array}{l}\text { Fibre } \\
(\mathrm{kg})\end{array} \\
\end{array}$ & $\begin{array}{l}\text { Initial } \\
\text { W/C }\end{array}$ & $\begin{array}{l}\text { Additional } \\
\text { Water }(\mathrm{kg})\end{array}$ & $\begin{array}{l}\text { Final } \\
\mathrm{W} / \mathrm{C}\end{array}$ \\
\hline$\overline{0.00 C T R}$ & 21.87 & 32.81 & 9.84 & 0.000 & 0.45 & 0.67 & 0.48 \\
\hline $0.25 \mathrm{ABF}$ & 21.87 & 32.81 & 9.84 & 0.161 & 0.45 & 1.21 & 0.50 \\
\hline $0.35 \mathrm{ABF}$ & 21.87 & 32.81 & 9.84 & 0.226 & 0.45 & 1.29 & 0.51 \\
\hline $0.45 \mathrm{ABF}$ & 21.87 & 32.81 & 9.84 & 0.290 & 0.45 & 1.39 & 0.51 \\
\hline $0.55 \mathrm{ABF}$ & 21.87 & 32.81 & 9.84 & 0.355 & 0.45 & 1.53 & 0.52 \\
\hline $0.35 \mathrm{UBF}$ & 21.87 & 32.81 & 9.84 & 0.226 & 0.45 & 1.59 & 0.52 \\
\hline
\end{tabular}

\subsubsection{Porosity Test}

The test for the porosity of the alkali-treated banana fibre ULFC was undertaken in line with the work of Kearsley and Wainwright [30] following the methods described by Cabrera and Lynsdale [31]. The test has been proven to be more effective than Mercury Intrusion Porosimetry (MIP). This test involved the use of vacuum saturation apparatus. Three test samples of dimension $45 \mathrm{~mm}$ in diameter $\times 50 \mathrm{~mm}$ in height were first put into a ventilated oven for 72 hours. The weight of the samples after oven drying was then recorded. Samples were, after that, placed into a desiccator and fully immersed in water for 72 hours. After which, the weight of the saturated samples was measured in air and in water (apparent weight).

\subsubsection{Compressive Strength Test}

The hardened concrete specimen's compressive strength was undertaken on alkali-treated and untreated banana ULFC of dimension $100 \times 100 \times 100$ $\mathrm{mm}$. The test was conducted in the concrete laboratory via a universal testing machine GOTECH GT7001 BS 300, with a 3000 kN load capacity. A compressive strength test was conducted using the load speed of $0.6 \mathrm{MPa} / \mathrm{sec}$, in line with BS EN 123902019 Part 3 [32]. Three samples were tested at each curing period, and the average of the three readings was recorded as the compressive strength at that time.

\subsubsection{Splitting Tensile Strength Test}

The splitting tensile strength test was carried out using test samples of dimension $100 \mathrm{~mm}$ in diameter $\times 200$ $\mathrm{mm}$ in height. The cylindrical samples were tested using the same universal testing machine used for compressive strength test. Speed for the test was also maintained at $0.6 \mathrm{MPa} / \mathrm{sec}$. Three samples were also chosen at each curing period and tested. The test was performed as per BS EN 12390- Part 6 [33].

\subsubsection{Flexural Strength Test}

The flexural strength of $600 \mathrm{~kg} / \mathrm{m}^{3}$ composite ULFC was undertaken using $100 \times 100 \times 500 \mathrm{~mm}$ prisms which were cast steel moulds. Similar to the compressive strength, three samples were tested for each of the curing periods and the mean of the three recorded readings was taken as a final flexural strength. The test was performed using an ELE flexural testing machine with a speed rate of $0.2 \mathrm{kN} / \mathrm{sec}$. A three-point bending test was undertaken using the test method as was described in BS EN 12390- Part 5 [34]

\subsubsection{Ultrasonic Pulse Velocity (UPV) Test}

A good parameter for the determination of concrete properties using a non-destructive approach is the ultrasonic pulse velocity. The test was performed in line with ASTM C597-16 [35]. This test method involves propagating longitudinal stress waves pulses through a concrete material of a given length dimension. Two transducers are involved. One transducer transmits an electro-acoustical pulse in a longitudinal direction at one surface of the test samples.

\subsubsection{SEM Micrograph}

Test samples obtained from the fracture surfaces of flexural specimens after 28 days of testing were cut into smaller sizes $20 \times 20 \times 20 \mathrm{~mm}$ and sandpapered or polished. The small specimens were taken for microstructural analysis through Scanning Electron Microscopy (SEM) from alkali-treated and untreated composite samples. A single specimen was prepared for each test samples and coated in gold. SEM was conducted using low and high magnification to understand the microstructure of the banana fibre in the cement matrix of treated and untreated ULFC composite and the plain control.

\subsection{RESULTS AND DISCUSSION}

\subsection{Rheological Property}

Table 5 shows the various densities and workability of the alkali-treated and untreated banana fibre ULFC composite. It also shows the variation in the base mix's workability and the FC composite mix to the quantity of fibre added to each mix. From the table, $722 \mathrm{~kg} / \mathrm{m}^{3}$ was the designed plastic or wet density of the mix. The designed plastic density serves as a guide during the introduction of the foam into the composite-based mix. 
During this stage, care was taken to introduce sufficient foam to reduce the mortar density above the designed plastic density. For this reason, the actual plastic densities measured during the batching were within the range of $732-751 \mathrm{~kg} / \mathrm{m}^{3}$, all exceeding the designed plastic density of $722 \mathrm{Kg} / \mathrm{m}^{3}$. Therefore, the increased value of actual plastic density as fibre increases is deliberate not a sign of composite variation in the property as fibre content increases. The designed plastic density was calculated based on the assumption that the difference between the wet density and the targeted dry density is mostly equal to $100 \pm 20 \mathrm{~kg} / \mathrm{m}^{3}$ [36] Hence, that was why values obtained for targeted dry density were all between the range $615-639 \mathrm{Kg} / \mathrm{m}^{3}$.

Considering workability results, in Table 5 and Figure 3 , as fibre addition increases, spreadability or workability decreases. Reasons for the decrease in workability of both base mix and ULFC composite when the fibre was added to the fresh mix was because banana fibre is composed of hemicellulose, cellulose, lignin, pectin, which are hydrophilic and absorbs readily available water in the fresh mix. Despite the alkali treatment, a certain percentage of the amorphous hemicellulose and lignin remains, increasing water absorption. The crystalline cellulose polymer also absorbs a little amount of water.

In addition, the workability of alkali-treated and untreated banana fibre of the same fibre volume fraction $(0.35 \%)$ varies considerably. Figure 4 depicts the variation in spreadability of the alkali-treated and untreated banana fibre of the base mix and ULFC mix. reatment of banana fibre surfaces with $\mathrm{NaOH}$ cleans the fibre surfaces of amorphous hemicellulose, lignin, and pectin. The alkali-treated fibre surfaces became rich in mostly crystalline cellulose fibre, which is hydrophobic. Therefore, this reduces the water absorption compared to the untreated fibre.

Hence, the untreated banana fibre composite absorbs more water compared to the treated banana fibre composite. More water absorption resulted in the untreated banana fibre composite mix exhibiting lower spreadability than the treated banana fibre composite mix. The decrease in spreadability to the control of the alkali-treated banana fibre composite of the base mix and the FC composite mix (0.35ABF) is recorded as $10.25 \%$ and $7.27 \%$, respectively. Whereas the decrease in spreadability to the control of the untreated banana fibre reinforced composite of the base and the $\mathrm{FC}$ composite mix (0.35UBF) is reported as $16.78 \%$ and $19.71 \%$, respectively

Table 5 Fresh composite density and workability

\begin{tabular}{|c|c|c|c|c|c|}
\hline Batch & $\begin{array}{l}\text { Wet } \\
\text { density } \\
\left(\mathrm{kg} / \mathrm{m}^{3}\right)\end{array}$ & $\begin{array}{l}\text { Plastic } \\
\text { density } \\
\left(\mathrm{kg} / \mathrm{m}^{3}\right)\end{array}$ & $\begin{array}{l}\text { Final dry } \\
\text { density } \\
\left(\mathrm{kg} / \mathrm{m}^{3}\right)\end{array}$ & $\begin{array}{l}\text { Base mix } \\
\text { spreadability } \\
\text { (mm) }\end{array}$ & $\begin{array}{l}\text { Composite } \\
\text { mix spreadability } \\
\text { (mm) }\end{array}$ \\
\hline \multicolumn{2}{|c|}{0.00 CTR722 } & 732 & 615 & 217.5 & 275 \\
\hline \multicolumn{2}{|c|}{$0.25 A B F 722$} & 738 & 626 & 211.5 & 270 \\
\hline \multicolumn{2}{|c|}{$0.35 \mathrm{ABF} 722$} & 749 & 635 & 195.0 & 255 \\
\hline \multicolumn{2}{|c|}{$0.45 A B F 722$} & 751 & 639 & 190 & 240 \\
\hline \multicolumn{2}{|c|}{$0.55 \mathrm{ABF} 722$} & 747 & 633 & 185 & 227.5 \\
\hline \multicolumn{2}{|c|}{0.35 UBF 722} & 743 & 631 & 181 & 220.8 \\
\hline
\end{tabular}

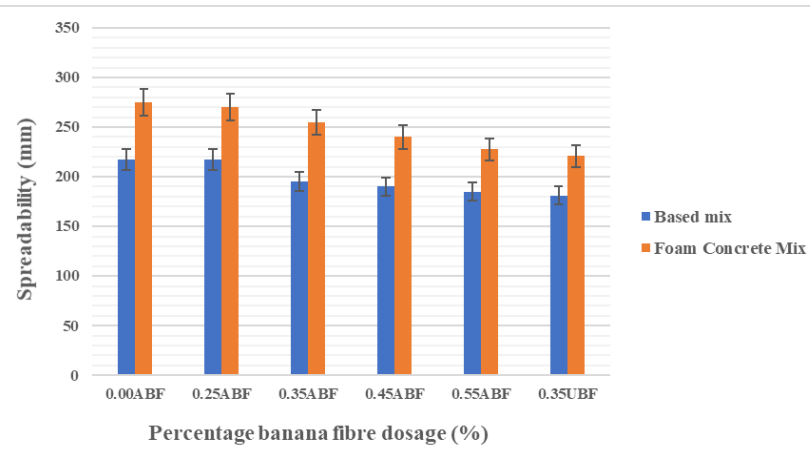

Figure 3 Workability of base mortar mix and alkali treated banana FRFC mix

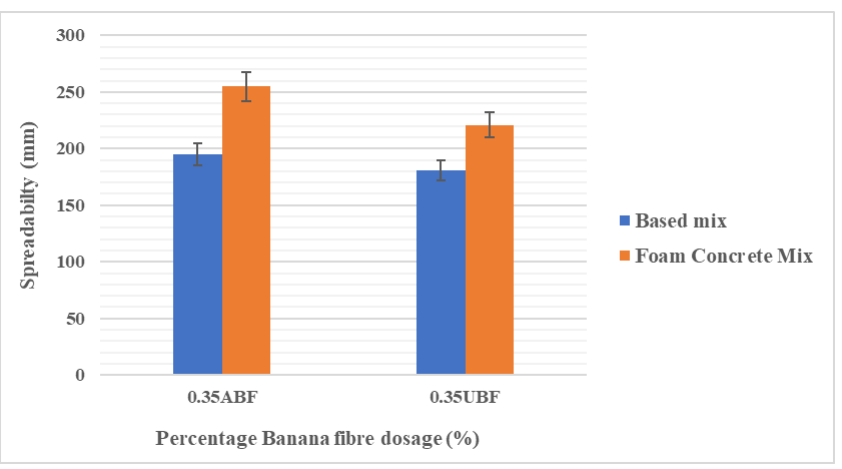

Figure 4 Workability of treated and untreated banana fibre

\subsection{Porosity of ULFC Composite}

Figure 5 shows the porosity of ULFC composite reinforced with alkali-treated banana fibre. The figure shows a decline in porosity with an increase in curing age. As ULFC composite cure from 7 to 90 days, watercement hydration continues with the production of calcium silicate hydrate $\mathrm{C}-\mathrm{S}-\mathrm{H}$ gel in the moist composite matrix, which results in more gels than voids and closed pore voids, which reduce the porosity of the composite material with time. The porosity values obtained for alkali-treated banana fibre ULFC ranges between $61.63-68.72 \%$. Figure 5 also indicates a slight increase in porosity as the fibre content increases. At 28 days curing age and to the control, the percentage increase in porosity for the fibre addition of $0.25 \mathrm{ABF}$, $0.35 \mathrm{ABF}, 0.45 \mathrm{ABF}, 0.55 \mathrm{ABF}$ and $0.35 \mathrm{UBF}$ was recorded as $1.28 \%, 1.78 \%, 3.02 \%, 4.30 \%$, and $6.15 \%$ with the highest percentage increase exhibited by the untreated banana fibre ULFC composite. A similar porosity increase with increasing fibre content was experienced at the curing ages of 7,14 , and 90 days. The increase in porosity might be related to the porous nature of the treated and untreated fibre [19].

The density of alkali-treated fibre and untreated banana fibre was given as $1.32 \mathrm{~g} / \mathrm{cc}$ and $1.25 \mathrm{~g} / \mathrm{cc}$, respectively. Thus, introducing these low-density materials could result in a slight increase in porosity. This finding is supported by a study undertaken by Steshenko et al. [21] who reported an increase in porosity as the fibre content increases. Castillo-Lara et al. [15] reported that incorporating alkali-treated and 
untreated henequin or polypropylene into $700 \mathrm{~kg} / \mathrm{m}^{3}$ in small or large quantities has no significant influence on the porosity of FRFC composite. It is important to note that the percentage increase in porosity reported in this study ranges between $1.28 \%-6.15 \%$. The range of porosity values for the FC starting from the control to the alkali-treated fibre ULFC and untreated fibre ULFC composite was $61.63 \%-68.72 \%$, which signifies slight difference between them. Comparing the ULFC composite with alkali-treated fibre with the untreated fibre of the same volume fractions shown in Figure 6, one can vividly see some visible differences in porosity. The porosity of untreated banana fibre ULFC composite at all curing age is higher than that of alkali-treated banana fibre composite. Compared to the control, an increase of $6.98 \%$ was recorded at 28 Days of curing for untreated banana fibre, while treated banana fibre composite recorded a $1.54 \%$ increment.

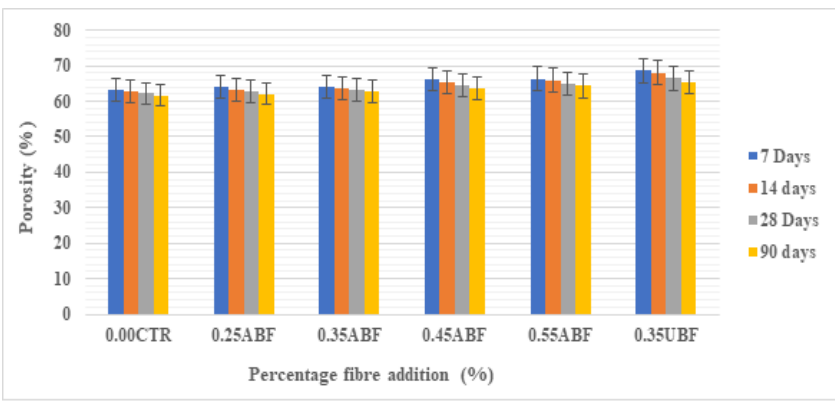

Figure $\mathbf{5}$ Variation of porosity with curing age

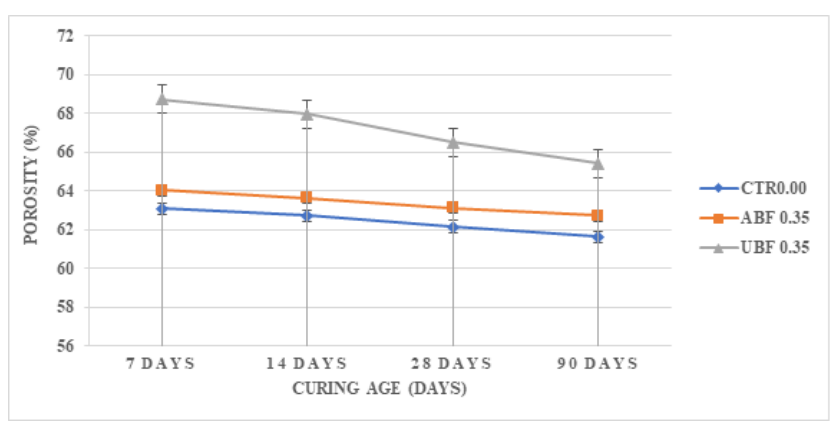

Figure 6 Variation of porosity with respect to fibre treatment

\subsection{Compressive Strength}

Figure 7 shows the graph of the variation in compressive strength to the percentage fibre addition. Results indicate that as the curing age increases from 7 to 90 days, composite compressive strength also increases from $0.8888 \mathrm{MPa}-1.4690 \mathrm{MPa}$. The increase is due to the continued hydration of cement in ULFC composite. Figure 7 depicts that at 28 days curing age, an increase in compressive strength of $13.85 \%, 24.48 \%$, $4.82 \%$ and $1.64 \%$ were recorded in the control specimen, when the percentage fibre volume fraction was 0.25ABF, 0.35ABF, 0.45ABF, and 0.55ABF, respectively. A similar trend of increase in compressive strength was reported for 7, 14- and 90-days curing periods, with $0.35 \mathrm{ABF}$ fibre volume fraction recording the highest increase in compressive strength. Therefore, the optimum percentage increase in compressive strength, as shown in the graph, is when the percentage alkali-treated banana fibre volume fraction is at $0.35 \mathrm{ABF}$. However, as the percentage fibre addition increases to $0.45 \mathrm{ABF}$ and $0.55 \mathrm{ABF}$ at 28 days, the percentage increase in compressive strength recorded were $4.82 \%$ and $1.64 \%$, respectively, compared to the control. This decline in percentage increase in compressive strength resulted from balling effect when the excess fibre was introduced to ULFC $\mathrm{Xu}$ et al.; Raj et al. [10,37]. When fibre content is in excess, as was revealed by $0.45 \mathrm{ABF}$ and $0.55 \mathrm{ABF}$ fibre addition, workability decreases, mixing becomes so difficult, fibres stick to the concrete mixer blades, a lot of balling is produced and therefore ineffective dispersion of the fibres occurs, which results to loss or decrease in strength. Therefore, the optimum percentage of alkali-treated banana fibre addition is at $0.35 \mathrm{ABF}$. The percentage increase in compressive strength recorded is $24.48 \%$ compared to $22 \%$ reported by Raj et al. [37] at $0.30 \%$ treated coir fibre volume fraction in FRFC composite. Fedorov and Mestnikov [24] reported a compressive strength of 1.9 MPa to 1.4 MPa plain control, using cellulose fibre reinforced foam concrete of density $600 \mathrm{~kg} / \mathrm{m}^{3}$ optimum fibre addition of $0.3 \%$.

A similar trend of increment in compressive strength is indicated at curing ages of 7, 14 and 90 days compared to the control. The reasons for alkali-treated banana fibre performing better than the counterpart untreated banana fibre in FC composite as depicted in Figure 8, was because alkali treatment of fibre surfaces cleans amorphous hemicellulose, lignin and pectin of banana fibre and improves the surface adhesion of fibre with cement matrix. The cleaning also results in bundle fibrils defibrillation, leading to the increased surface area of the banana fibre and the creation of more interfacial surfaces for cement matrix adhesion.

The defibrillated bundle fibrils can be seen much vividly from the SEM micrograph of treated and untreated banana fibre shown in Figure 15 (a)(b). This result is similar to that of Joaquin et al. [15] and Fedorov and Mestnikov [24]. The results also imply that ULFC composite of both treated and untreated banana fibre perform better than the control ULFC.

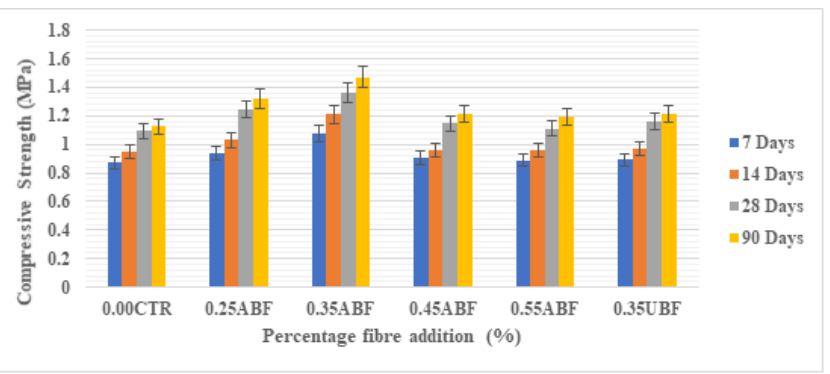

Figure 7 Variation of compressive strength with respect to fibre addition 


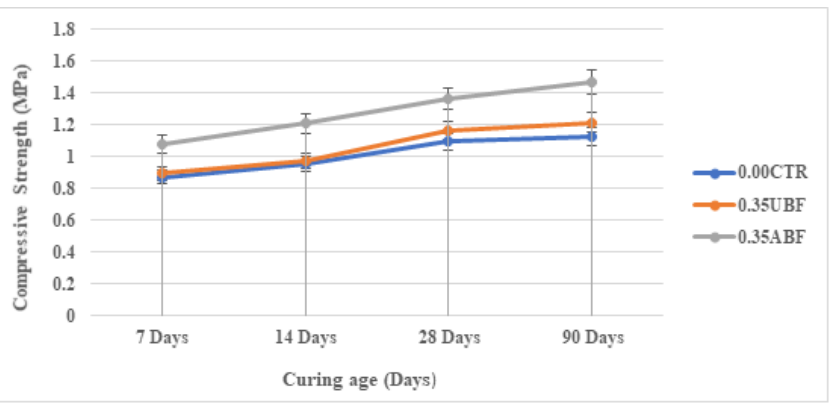

Figure 8 Variation of compressive strength with respect to banana fibre treatment

\subsection{Flexural Strength}

The flexural strength of alkali-treated banana fibre ULFC as per the fibre content addition is shown in Figure 9. A similar trend of finding as was discussed for compressive strength is visible in terms of flexural strength. Figure 8 indicates that as the curing age of the alkali-treated banana fibre ULFC composite increases, the bending strength also increases. Also, the bending strength of alkali-treated banana fibre ULFC increases vigorously with an increase in the fibre percentage volume fraction. Compared to the control and at 7days early curing age, Figure 8 indicates an increase in flexural bending strength of $21.11 \%, 33.58 \%, 22.11 \%$ and $5.05 \%$ when the alkali-treated banana fibre volume fraction increases from 0.25ABF, 0.35ABF, 0.45ABF to 0.55ABF, respectively. With $0.35 \mathrm{ABF}$ volume fraction exhibiting the highest increase in strength.

Considering 28 Days of curing age and to the control, an increase in alkali-treated banana fibre volume fraction of $0.25 \mathrm{ABF}, 0.35 \mathrm{ABF}, 0.45 \mathrm{ABF}$ and $0.55 \mathrm{ABF}$ resulted in a corresponding increase in flexural strength of $29.14 \%, 30.65 \%, 18.88 \%$ and $9.59 \%$, respectively. This trend of increase in bending strength is displayed vividly in Figure 9 at the curing age of 14 and 90 days, with the optimal increase in strength in all cases experienced at an alkali-treated banana fibre volume fraction of $0.35 \mathrm{ABF}$. The optimum percentage flexural strength increase achieved with the banana fibre volume fraction of $0.35 \mathrm{ABF}$ to the control at 28 days hydration is $30.65 \%$. This finding is similar to the work conducted by Raj et al. [34] [37] using $0.30 \%$ coir fibre volume fraction in FC composite recorded a $22 \%$ increase in flexural strength at 28 days hydration to the control.

Considering Figure 10, alkali treatment of banana fibre result in a tremendous increase in flexural strength of alkali-treated fibre ULFC composite compared to the untreated fibre composites. The result indicates that alkali-treated banana fibre ULFC composite experience an increase in flexural strength of $33.58 \%$, $42.70 \%, 30.65 \%$, and $24.60 \%$ compared to untreated banana fibre composite, with an increase in strength of $3.82 \%, 6.24,4.68 \%$ and $4.19 \%$ all respectively, at the curing periods of $7,14,28$ and 90 days to the control. At 28 days curing periods, the increase in flexural strength exhibited by the alkali-treated banana fibre composite was $30.65 \%$, while that for untreated banana composite was $4.68 \%$.

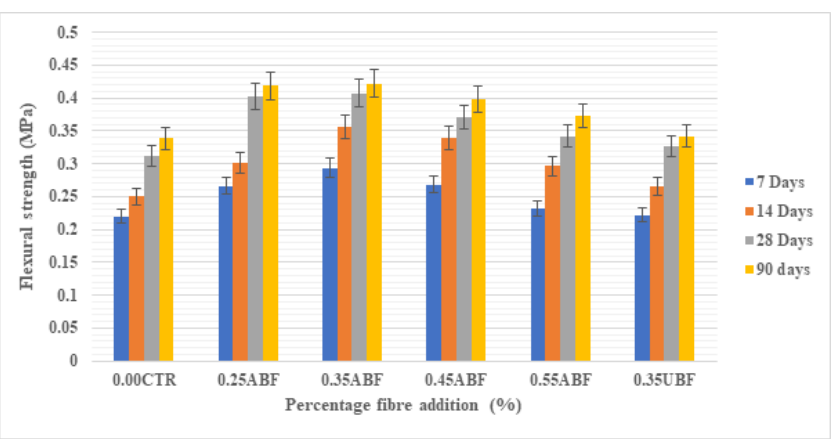

Figure 9 Variation of flexural strength with respect to fibre addition

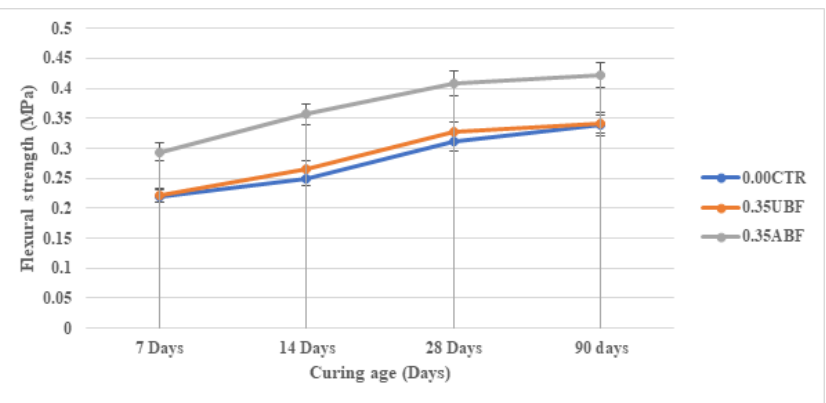

Figure 10 Variation of flexural strength with respect to banana fibre treatment

\subsection{Splitting Tensile Strength}

Figure 11 shows the result of variation of splitting tensile strength to alkali-treated banana fibre addition. The result also reveals the ULFC composite' changes due to curing age on the splitting tensile strength. From Figure 11, irrespective of the fibre volume fraction, split tensile strength increases as the hydration periods increases. Figure 11 also implied that as the percentage fibre volume fraction increases, splitting tensile strength increases compared to the control. Results from Figure 10 indicate that at 28 days hydration period and with respect to the control, split tensile strength increases from $19.55 \%, 29.12 \%, 14.50 \%$ to $15.57 \%$, when the fibre volume fraction addition increases from $0.25 \mathrm{ABF}$, $0.35 \mathrm{ABF}, 0.45 \mathrm{ABF}$ to $0.55 \mathrm{ABF}$. This increase in split tensile strength as the banana fibre content increases is exhibited by the remaining hydration periods of 7,14 and 90 days. Castillo-Lara et al. [15] reported a $98 \%$ increase in tensile strength of a treated henequin fibre of $700 \mathrm{~kg} / \mathrm{m}^{3}$ composite compared to the plain control samples, while Awang et al. [38] recorded a $20.4 \%$ increase in tensile strength of a treated kenaf fibre at the volume fraction of $0.40 \%$ on a $1000 \mathrm{~kg} / \mathrm{m}^{3}$ composite compared to the control.

Figure 12 gives a pictorial difference in splitting tensile strength of the alkali-treated banana fibre composite and the untreated banana fibre to the control unreinforced ULFC. The figure clearly shows that 
the alkali-treated banana fibre ULFC composite performs better at all curing age than the untreated banana fibre ULFC composite. Finding from the figure indicates that at the curing ages of 7, 14, 28 and 90 days, the alkali-treated banana fibre composite recorded an increase in percentage tensile strength of $31.87 \%$, $30.51 \%$, $29.12 \%$, and $22.66 \%$, respectively, compared to the percentage increase in tensile strength for the untreated composite of $4.90 \%, 3.77 \%$, $5.88 \%$ and $3.92 \%$ to the control. This variation in tensile strength of alkali-treated banana fibre compared to untreated banana fibre is credited to the ability of the $\mathrm{NaOH}$ to clean surfaces of banana fibre of debris, lignin, pectin, and hemicellulose and improve fibre adhesion of cement matrix. Alkali treatment of fibre surface increases material toughness by roughening the fibre's surface, resulting in a better fibre-matrix bond and higher frictional pull-out.

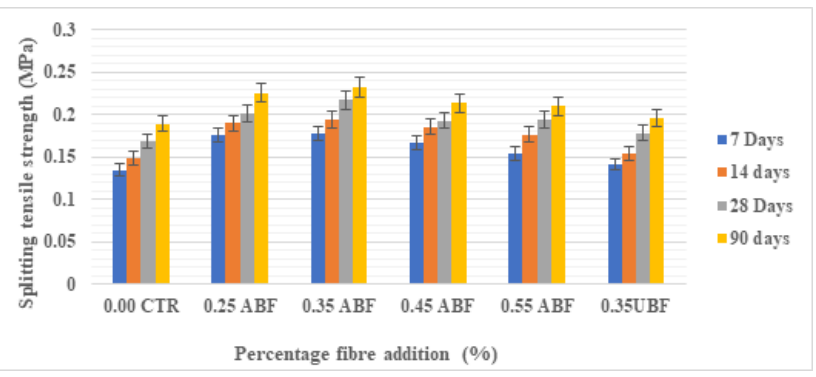

Figure 11 Variation of tensile strength with respect to fibre addition

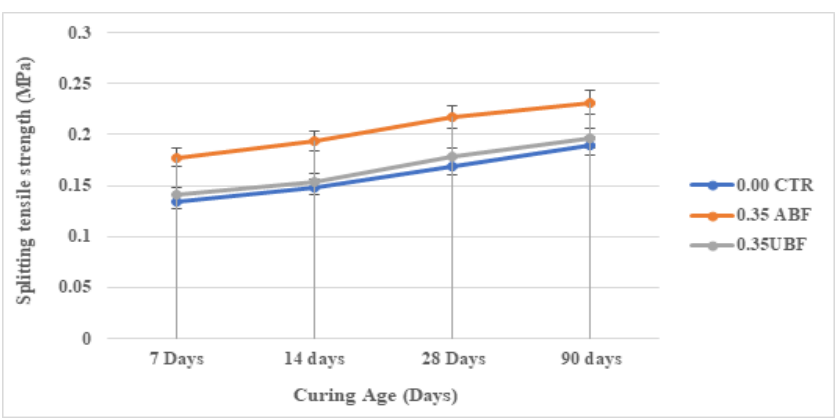

Figure 12 Variation of splitting tensile strength with respect to banana fibre treatment

\subsection{Ultrasonic Pulse Velocity (UPV)}

Figure 13 shows the variation of UPV of alkali-treated fibre ULFC composite per fibre volume fraction addition. The composite' UPV increases with an increase in curing ages of the composite. The increase is attributed to continuous hydration of $\mathrm{C}-\mathrm{S}-\mathrm{H}$ gel with curing periods. The gel formation reduces micro-cracks and increases the production of closed micropore and air voids, increasing UPV. Since moist plastic wrapping curing is adopted, moisture is trapped, and hydration processes continue up to demoulding and testing. Therefore, the longer the curing age, the better the cement matrix's ability to continue the $\mathrm{C}-\mathrm{S}-\mathrm{H}$ gel formation, the higher the UPV.
Figure 13 also indicates a continued increase in UPV with an increase in alkali-treated banana fibre volume fraction in the ULFC composite up to the optimum volume fraction of $0.35 \mathrm{ABF}$. As the alkali-treated fibre volume fraction increases from 0.25ABF, 0.35ABF, $0.45 \mathrm{ABF}$ to $0.55 \mathrm{ABF}$, percentage increase in ultrasonic pulse velocity also improves from $9.55 \%, 14.07 \%, 5.03 \%$, to $3.02 \%$ respectively, at 28 days curing age and compared to the control. The highest percentage increase in UPV was $14.07 \%$ recorded at the fibre fraction of $0.35 \mathrm{ABF}$ at 28 days compared to the control. Similar to the other strength parameters in previous sections, after the peak percentage increase in UPV of $14.07 \%$ at $0.35 \mathrm{ABF}$ volume fraction, there is a slight decline in percentage increase in the UPV at the fibre volume fraction of $0.45 \mathrm{ABF}(5.03 \%)$ and $0.55 \mathrm{ABF}(3.02 \%)$. At 28 days curing age and to the control, the UPV of the $0.35 \mathrm{ABF}$ volume fraction treated fibre composite was $1135 \mathrm{~m} / \mathrm{s}(14.07 \%)$ than the UPV of the $0.35 \mathrm{ABF}$ volume fraction of untreated fibre composite with $1035 \mathrm{~m} / \mathrm{s}(4.01 \%)$ as display in Figure 14.

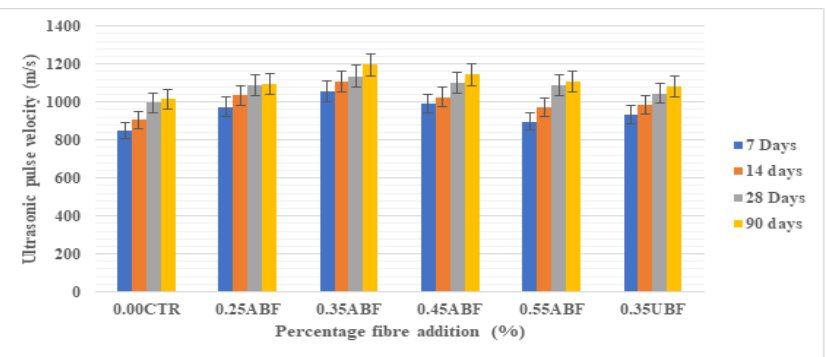

Figure 13 Variation of ultrasonic pulse velocity with respect to fibre volume fraction

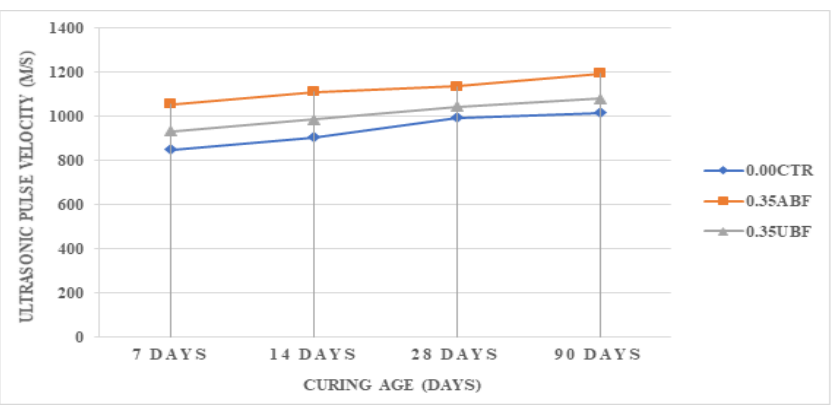

Figure 14 Variation of ultrasonic pulse velocity with respect to fibre treatment

\subsection{SEM Microstructural Analysis}

Figure 15 shows the micrograph of the surfaces of the treated and untreated banana fibre. The figure reveals the scaly nature of both fibres. The scaly lines on the surfaces of both fibres indicate the multicellular bundle nature of banana fibre microstructure. However, Figure 15(a) for untreated banana fibre surface shows impurities and debris on surfaces which is detrimental to the proper interfacial adhesion of fibre surface with cement matrix. Figure 15(b) for treated banana fibre in contrast to the untreated shows a very rough defibrillated surface that is good for surface adhesion 
and improves the cement matrix's mechanical property. The rough surface also reveals isolated fibrils, which are defibrillated from the treatment with an alkaline solution. The isolated fibrils increase the treated banana fibre's surface area and, therefore, leads to better adhesion of the fibres with the cement matrix gel. These differences in the two fibres' surfaces are responsible for differences in all mechanical properties tested, in which case alkali-treated banana fibre ULFC composite had shown great enhancement in compressive, flexural, splitting tensile strength, and UPV.

Figure 16 is the cross-section of the untreated banana as well as the treated banana fibre. The figure indicated in both cases the presence of lumen and scaly bundle fibrils of the banana fibre. In both cases, the lumen's presence is responsible for the porous and very lightweight fibres, as given in Table 3 . The bundle fibrils give rise to the scaly longitudinal lines on both fibre surfaces, increasing the fibre's porosity. However, Figure 16(a) for the treated banana fibre has revealed numerous small and large lumen compared to Figure 16(b) for treated banana fibre. The numerous small and large lumen implies that the untreated banana fibre is more porous and lighter than the treated banana fibre. The lumen shown in Figure 16(b) are very few and small compared to the one shown in Figure 16(a). Most of the lumen in Figure 16(b) has collapsed due to the alkali treatment undertaken on them.

Figure 17 shows the microstructure of the ULFC of the untreated and treated composite compared to the plain control matrix. Figure 17(a) reveals how the untreated fibre lies freely and isolated in the cement matrix of ULFC. The visible scaly longitudinal lines seen in the micrograph is good evidence of a lack of bonding with cement gel matrix. The poor bonding could result from the impurities and debris and smooth surfaces of untreated fibre, as seen in Figure 15(a). The poor interfacial bond associated with untreated fibre is responsible for poor mechanical strength exhibited by ULFC composite reinforced with untreated fibre. Figure 17(b) shows treated banana fibres that are well encapsulated to the cement gel surfaces. The fibre surfaces are covered with $\mathrm{C}-\mathrm{S}-\mathrm{H}$ gel because of the improved surface area and very deformed rough surfaces of the treated fibre. Figure 17(c) shows the micrograph of the plain control ULFC, which reveals uneven air voids. The difference between the untreated and treated ULFC composites is primarily in how the banana fibre is covered with cement gel. For the untreated, the visible scales in the micrograph of the fibre are the sign of poor cement paste encapsulation (Figure 17a). In contrast, the fibres are encapsulated by cement gel for the treated banana fibre in ULFC composites (Figure 17b). In addition, the number of micropores and merged macropores is not the same in the two micrographs. Untreated banana fibre composite exhibited more micropores and merged air voids than the treated banana fibre composite. Besides, the untreated micrographs display a series of microcracks which is not seen in the treated micrograph. All these differences are responsible for increased strength and integrity in treated banana fibre ULFC composite compared to untreated.
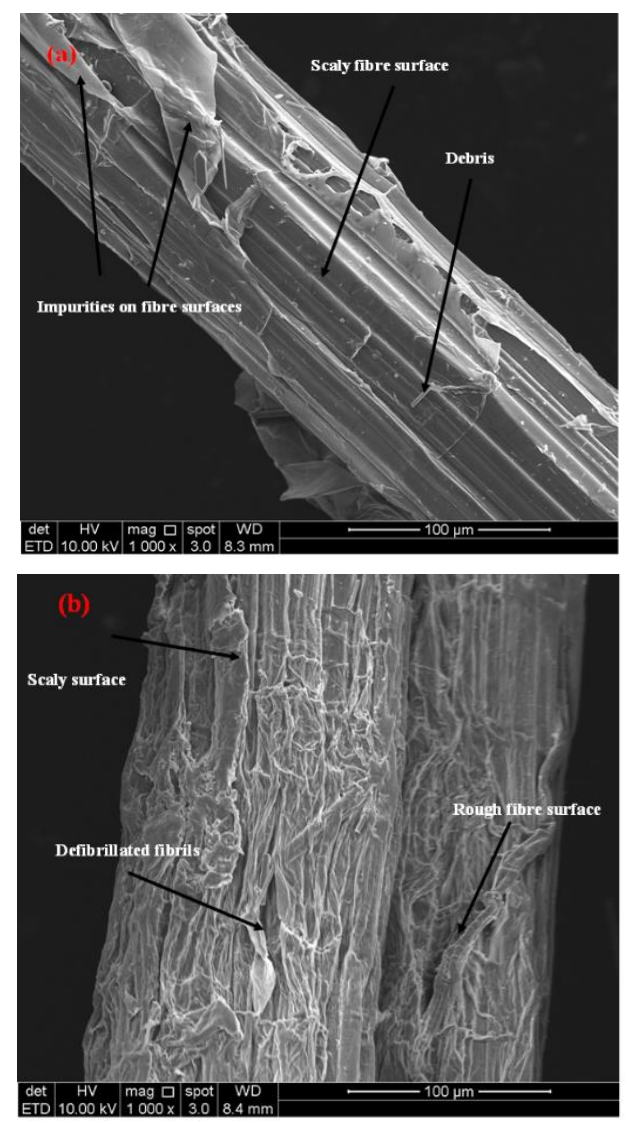

Figure 15 Banana fibre surfaces (a) untreated fibre (b) treated fibre

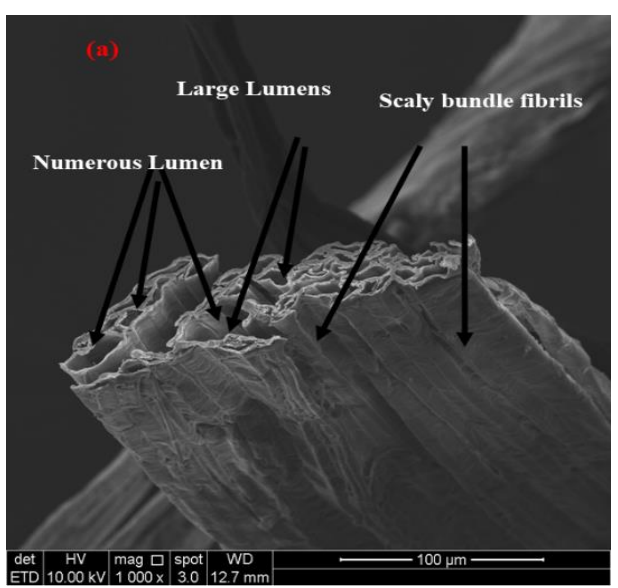




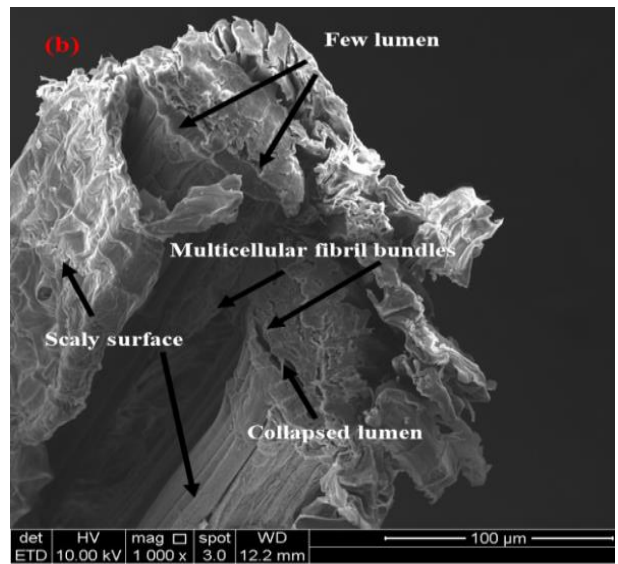

Figure 16 Banana fibre cross sections (a) untreated fibre (b) treated fibre
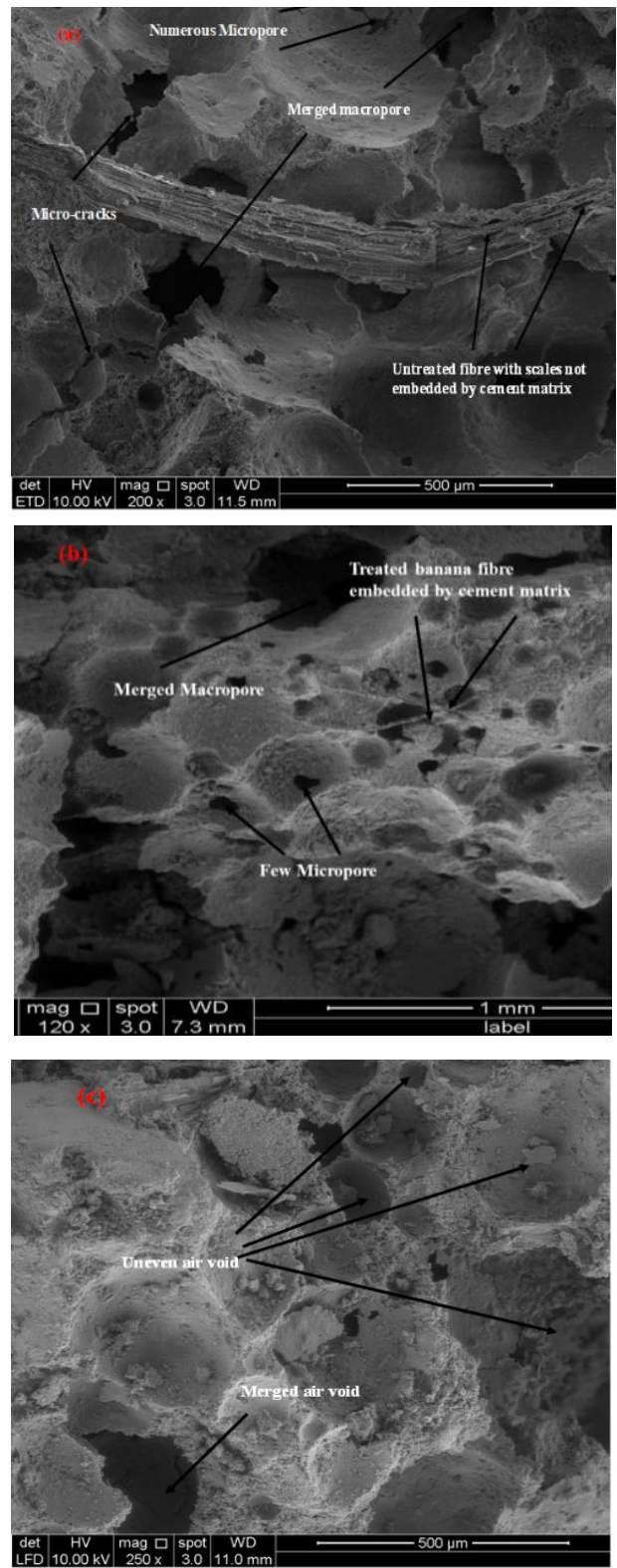

Figure 17 ULFC composites (a) untreated fibre ULFC (b) Treated fibre ULFC (c) control composite

\subsection{CONCLUSION}

This research investigated the fresh and hardened mechanical properties of ULFC reinforced with alkalitreated and untreated banana fibre. Physical properties such as porosity, density and microstructure were also studied and reported. Workability or spreadability of ULFC reinforced with alkali-treated banana fibre reduces with an increase in fibre content. The spreadability reduces further when the untreated banana fibre is used in contrast with alkali-treated banana fibre. A pronounced increase in porosity was observed with untreated banana fibre compared to any volume fraction of alkali-treated banana fibre.

An optimum percentage increase of $24.48 \%$ in compressive strength was recorded with an alkalitreated banana fibre content of 0.35ABF compared to the control ULFC. In terms of flexural strength, an optimum percentage increase of $30.65 \%$ was reported at an alkali-treated banana fibre volume fraction of $0.35 \mathrm{ABF}$. The optimum percentage increase of $29.12 \%$ was documented for splitting tensile strength at the alkali-treated banana fibre volume fraction of $0.35 \mathrm{ABF}$ compared to the control. A similar trend of the optimum mechanical property was also reported for a non-destructive UPV test with an increment of $14.07 \%$ at the alkali-treated banana fibre volume fraction of $0.35 \mathrm{ABF}$ to the control. The improved interfacial bond of the treated banana fibre with cement matrix is responsible for increment in the composite' mechanical property.

The ULFC reinforced with alkali treated banana fibre, produced with a very high porosity and low mechanical property is recommended for an infill material in sandwich composite panels. Further study is required to determine the durability performance and thermal property of the treated and untreated fibre in cement matrix

\section{References}

[1] Othuman Mydin, M. A., Noordin, N. M., Utaberta, N., Mohd Yunos, M. Y. \& Segeranazan, S. 2016. Physical Properties of Foamed Concrete Incorporating Coconut Fibre. J Teknol. 78(5): 99-105.

[2] Fu, Y., Wang, X., Wang, L. \& Li, Y. 2020. Foam Concrete: A State-of-the-Art and State-of-the-Practice Review. Advances in Materials Science and Engineering. 1-25

[3] Raj, A., Sathyan D, \& Mini, K. M. 2019. Physical and Functional Characteristics of foam Concrete: A Review. Construction and Building Materials. 221: 787-99.

[4] Elshahawi, M, \& Hückler, A. 2020. Infra Lightweight Concrete: A Decade of Investigation ( A Review ). Struct Concr. 22: $152-68$.

[5] Bing, C., Zhen, W., \& Ning L. 2012. Experimental Research on Properties of High-Strength Foamed Concrete. J Mater Civ Eng. 24(1): 113-8.

[6] Falliano, D., De Domenico, D., Ricciardi, G. \& Gugliandolo, E. 2019. Compressive and Flexural Strength of Fiber-reinforced Foamed Concrete: Effect of Fiber Content, Curing Conditions and Dry Density. Constr Build Mater. 198: 479-93.

[7] Awang, H. \& Ahmad, M. H. 2014. Durability Properties of Foamed Concrete with Fiber Inclusion. Int J Civil, Struct Constr Archit Eng. 8(3): 273-6. 
[8] Othuman Mydin, M. A., Ganesan, S., Mohd Yunos, M. Y., Utaberta, N. \& Ismail, N. A. 2016. Structural Behaviour of Coir Fibre Reinforced Foamed Concrete Wall Panel System. J Teknol. 5(78): 169-77.

[9] Sahu, P, \& Gupta, M. K. 2020. A Review on the Properties of Natural Fibres and Its Bio-composites: Effect of alkali Treatment. J Mater Des. 234(1): 198-217.

[10] Xu, R., He, T., Da, Y., Liu, Y., Li, J. \& Chen, C. 2019. Utilizing Wood Fiber Produced with Wood Waste to Reinforce Autoclaved Aerated Concrete. Constr Build Mater. 208: 2429.

[1 1] Hasan, K. M. F., Horváth, P. G. \& Alpár, T. 2021. Lignocellulosic Fiber Cement Compatibility: A State of the Art Review. J Nat Fibers. 00(00):1-26.

[12] Vo, L. T. T. \& Navard, P. 2016. Treatments of Plant Biomass for Cementitious Building Materials - A Review. Construction and Building Materials. 121: 161-76.

[13] Akinyemi, B. A. \& Dai, C. 2020. Development of Banana Fibers and Wood Bottom Ash Modified Cement Mortars. Constr Build Mater. 241: 118041.

[14] Dhawan, A., Gupta, N., Goyal, R. \& Saxena, K. K. 2020. Evaluation of Mechanical Properties of Concrete Manufactured with Fly Ash, Bagasse Ash and Banana Fibre. Mater Today Proc. 2020: 6-11.

[15] Castillo-Lara, J. F., Flores-Johnson, E. A., Valadez-Gonzalez, A., Herrera-Franco, P. J., Carrillo, J. G., Gonzalez-Chi, P. I., et al. 2020. Mechanical Properties of Natural Fiber Reinforced Foamed Concrete. Materials. 1-18.

[16] El Zareef, M. \& Schlaich, M. 2008. Infra-lightweight Concrete. In: Tailor Made Concrete Structures. CRC Press. 159-159.

[17] Falliano, D., De Domenico, D., Ricciardi, G. \& Gugliandolo, E. 2019. Improving the Flexural Capacity of Extrudable Foamed Concrete with Glass-fiber Bi-directional Grid Reinforcement: An Experimental Study. Compos Struct. 209: 45-59.

[18] Luo, J., Hou, D., Li, Q., Wu, C. \& Zhang, C. 2017. Comprehensive Performances of Carbon Nanotube Reinforced Foam Concrete with Tetraethyl Orthosilicate Impregnation. Constr Build Mater. 131: 5126.

[19] Yakovlev, G., Keriené, J., Gailius, A. \& Girniené. 2006. I. Cement Based Foam Concrete Reinforced by Carbon Nanotubes. Mater Sci. 12(2): 147-51.

[20] Batool, F. \& Bindiganavile, V. 2020. Fresh Properties of Fiber Reinforced Cement-Based Foam with Pozzolans. Iran J Sci Technol - Trans Civ Eng. 44: 253-264.

[21] Steshenko, A., Kudyakov, A., Konusheva, V., Syrkin, O. 2017. Structure Formation Control of Foam Concrete. AIP Conference Proceedings. 2017.

[22] Yu, C. 2015. Foam Concrete Performance Study based on Experimental Analysis. MATEC Web Conf. 25: 0-5.
[23] Pivarčiová, E., Božek, P., Domnina, K., Škultéty, E. \& Fedosov, S. 2019. Interferometric Measurement of Heat Transfer Above New Generation Foam Concrete. Meas Sci Rev. 19(4): 15360.

[24] Fedorov, V. \& Mestnikov, A. 2018. Influence of Cellulose Fibers on Structure and Properties of Fiber Reinforced Foam Concrete. MATEC Web Conf. 02008: 1-6.

[25] Brady, K. C., Watts, G. R. A. \& Jones, M. R. Specification for Foamed Concrete - Prepared for quality Services, Civil Engineering, Higways Agency. Crowthorne: TRL Limited.

[26] BS EN 197-1: 2011. Cement Part 1: Composition, Specifications and Conformity Criteria for Common Cements. Br Stand Inst.

[27] Nensok, M. H., Mydin, A. O. \& Awang, H. 2021. Investigation of Thermal, Mechanical and Transport Properties of UltraLightweight Foamed Concrete (ULFC) Strengthened with Alkali Treated Banana Fibre. J Adv Res Fluid Mech Therm Sci. 1(1): 17-32.

[28] BS EN 12350-6 2019. Testing Fresh Concrete Part 6: Density. Br Stand Inst.

[29] ASTM C 1611/C1611M:18. 2018. Standard Test Method for Slump Flow of Self-Consolidating Concrete 1. Am Soc Test Mater. 1-6.

[30] Kearsley, E. \& Wainwright, P. Porosity and Permeability of Foamed Concrete. Cem Concr Res. 31 (5): 805-12.

[31] Cabrera, J. G. \& Lynsdale, C. J. 1988. A New Gas Permeameter for Measuring the Permeability of Mortar and Concrete. Mag Concr Res. 40(144): 177-82.

[32] BS EN 12390-19 Part 3. 2019. Testing Hardened Concrete: Compressive Strength of Test Specimens. Br Stand Inst. 4-10.

[33] BS EN 12390-6. 2010. Testing Hardened Concrete - Part 6 : Tensile Splitting Strength of Test Specimens. BSI Stand Publ. 3(1): 10.

[34] BS EN 12390-5. 2019. Testing Hardened Concrete Part 5: Flexural Strength of Test Specimens. BSI Stand Publ. 1-22.

[35] ASTM C 597-16. 2016. Standard Test Method for Pulse Velocity through Concrete. Am Soc Test Mat. 04(02): 3-6.

[36] Amran, Y. H. M., Farzadnia, N. \& Ali, A. A. A. 2015. Properties and Applications of Foamed Concrete; A Review [Internet]. Construction and Building Materials. 101: 990-1005.

[37] Raj, B., Sathyan, D., Madhavan, M. K. \& Raj, A. 2020. Mechanical and Durability Properties of Hybrid Fiber Reinforced Foam Concrete. Constr Build Mater. 245.

[38] Awang, H., Ahmad, M. H. \& Al-Mulali, M. Z. 2015. Influence of Kenaf and Polypropylene Fibres on Mechanical and Durability Properties of Fibre Reinforced Lightweight Foamed Concrete. J Eng Sci Technol. 10(4): 496-508. 